\title{
Najnowsze doniesienia kardiologiczne znad Potomaku - relacja z kongresu American College of Cardiology Waszyngton, 17-19 marca 2017
}

\author{
Cardiology news from the Potomac River - late breaking clinical trials \\ at $66^{\text {th }}$ annual Scientific Sessions of the American College of Cardiology \\ March 17-19, 2017, Washington, DC
}

\author{
Aleksandra M. Mamzer-Dachnowska, Jarosław D. Kasprzak \\ Katedra i Klinika Kardiologii Uniwersytetu Medycznego w Łodzi
}

\begin{abstract}
Wstęp
Podczas ostatniego kongresu American College of Cardiology (ACC), który odbywał się w Waszyngtonie od 17 do 19 marca 2017 roku, przedstawiono wyniki wielu ważnych badań klinicznych, w tym między innymi dotyczących kardiologii interwencyjnej. Poniżej omówiono najciekawsze z nich (wg subiektywnej oceny autorów).
\end{abstract}

\section{Stenoza aortalna}

Jednym z najbardziej eksponowanych na kongresie ACC badań klinicznych, umieszczonych jako prezentacja w sesji plenarnej inaugurującej kongres, było badanie SURTAVI (Surgical or Transcatheter Aortic-Valve Replacement in Intermediate-Risk Patients). Porównywano w nim odległe wyniki przezcewnikowej wymiary zastawki aortalnej (TAVR, trancatheter aortic valve replacement) z konwencjonalna metodą chirurgiczną (SAVR, surgical aortic valve replacement) u chorych z ciężką, objawową stenozą aortalną oraz cechujących się pośrednim ryzykiem operacyjnym. Obecnie TAVR stanowi akceptowaną metode leczenia chorych obciążonych wysokim ryzykiem operacyjnym, natomiast nie było odpowiedniej ilości danych potwierdzających celowość stosowania tej metody u pacjentów wykazujących ryzyko pośrednie. Do badania włączono 1660 pacjentów w 87 ośrodkach w Stanach Zjednoczonych, Kanadzie oraz Europie (randomizacja do leczenia SAVR:TAVR - 1:1). W grupie TAVR zastosowano samorozprężalne zastawki CoreValve ${ }^{\circledR}$ (Medtronic Inc., Minneapolis, USA) oraz nowe bioprotezy
Evolut- $R^{\circledR}$ (16\%). Kardiochirurdzy wykonujący SAVR mogli wybrać dowolną bioprotezę. Średni wiek pacjentów wynosił 79 lat, około 43\% stanowiły kobiety, a u około 60\% chorych współistniała niewydolność serca w III/IV klasie niewydolności według New York Heart Association (NYHA). Wszystkich pacjentów cechowało pośrednie ryzyko operacyjne (STS PROM, society of thoracic surgeons predicted risk of mortality) 4,4 $\pm 1,5$ i 4,5 $\pm 1,6$ odpowiednio w grupach TAVR $(n=864)$ i SAVR $(n=796)$. Pierwszorzędowy punkt końcowy - obejmujący zgon z jakiejkolwiek przyczyny lub ciężki udar w obserwacji 2-letniej - wystąpił z podobną częstością w grupach TAVR i SAVR, podobnie jak ryzyko zgonu z dowolnej przyczyny (2,2 v. 1,7\% pacjentów w ciągu 30 dni, 6,7 v. $6,8 \%$ w ciągu roku oraz 11,4 v. $11,6 \%$ w ciągu 2 lat). Wyraźny trend dotyczył poważnego udaru niedokrwiennego mózgu, który wystąpił u 2,6\% chorych z grupy TAVR oraz u 4,5\% w grupie SAVR - różnica ta nie osiągnęła jednak istotności statystycznej. Po zawężeniu analiz do okresu okołooperacyjnego (30 dni) stwierdzono jednak, że ryzyko wystąpienia jakiegokolwiek udaru mózgu było znamiennie niższe w grupie TAVR (3,4\% v. 5,6\%). Metoda przezcewnikowa wiązała się ponadto z niższym ryzykiem ostrego uszkodzenia nerek (1,7\% v. 4,4\%), migotania przedsionków (12,9\% v. 43,4\%) oraz konieczności transfuzji z powodu dużego krwawienia (58,9\% v. 87,5\%). Z kolei w grupie leczonej TAVR częściej występowały większa niż łagodna rezydualna niedomykalność aortalna ( $5 \%$ v. 1\%) oraz konieczność implantacji kardiostymulatora (25,9\% v. 6,6\%), co jest najprawdopodobniej związane z ciągle jeszcze udoskonalaną metodą pozycjonowania protezy,

Adres do korespondencji: lek. Aleksandra Mamzer-Dachnowska, Katedra i Klinika Kardiologii, Uniwersytet Medyczny w Łodzi,

Szpital im. W. Biegańskiego, ul. Kniaziewicza 1/5, 91-347 Łódź, tel. 4265399 09, e-mail: a.mdachnowska@gmail.com 
a także jej rodzajem i wydaje się, że w miare zdobywania doświadczenia, problem ten może zostać rozwiązany lub choćby zminimalizowany. Badania echokardiograficzne wykazały jednak dość niespodziewanie, że średni gradient na zastawce aortalnej w grupie TAVR był znacznie niższy (7,8\% v. $11,8 \%$ w ciągu 2 lat), a pole otwarcia zastawki aortalnej (AV) znacznie większe $\left(2,2 \mathrm{~cm}^{2}\right.$ v. $1,7 \mathrm{~cm}^{2}$ po 2 latach) niż w grupie poddanej leczeniu chirurgicznemu w każdym punkcie czasowym po zabiegu.

W badaniu SURTAVI udowodniono, że TAVR jest tak samo skuteczną metodą leczenia jak SAVR u chorych cechujących się pośrednim ryzykiem operacyjnym. Należy zauważyć, że operatorzy wykonujący TAVR mają dużo mniejsze doświadczenie niż ich koledzy, którzy operują konwencjonalnie od dziesięcioleci, a należy podkreślić, że w badaniu SURTAVI osiągnięto najlepsze w historii badań wyniki kliniczne w grupie „chirurgicznej”. Metoda TAVR jest zabiegiem mniej czasochłonnym, związanym z krótszym pobytem w szpitalu oraz szybszym powrotem do pełnej sprawności. Pacjentów leczonych SAVR cechowały jednak niższe wskaźniki późniejszych reinterwencji i rehospitalizacji związanych z zastawką aortalną. Wyniki te (zgodne z wcześniejszym badaniem PARTNER 2A) mogą zmienić sposób postępowania w ciężkiej objawowej stenozie aortalnej u pacjentów wykazujących pośrednie ryzyko operacyjne i przechylić szalę korzyści na stronę metody mniej inwazyjnej, w większym stopniu preferowanej przez chorych [1], co już znalazło wyraz w aktualizacji wytycznych amerykańskich [2].

Kolejnym interesującym doniesieniem, dotyczącym wymiany zastawki aortalnej, była identyfikacja zjawiska subklinicznej zakrzepicy na płatkach protez aortalnych, implantowanych konwencjonalnie (SAVR) oraz przezcewnikowo (TAVR). Bezobjawowa zakrzepica na płatkach bioprotez jest wykrywalna w badaniu tomograficznym (CT, computed tomography) i jest przyczyną gorszej ruchomości płatków zastawki. Badanie zaprojektowano tak, aby ocenić rozpowszechnienie i wpływ na hemodynamikę pracy zastawki bezobjawowej zakrzepicy na płatkach bioprotez oraz skuteczności doustnych antykoagulantów niebędących antagonistami witaminy K (NOAC (non-vitamin Kantagonist oral anticoagulants) w celu jej eliminacji. Było to badanie obserwacyjne, przeprowadzone na podstawie dwóch rejestrów RESOLVE (The Assessment of Transcatheter and Surgical Aortic Bioprosthetic Valve Thrombosis and its Treatment with Anticoagulation registry) oraz SAVORY (The Subclinical Aortic Valve Bioprosthesis Thrombosis Assessed with Four-Dimensional Computed Tomography registry). Wśród 931 pacjentów, których poddano badaniu CT (657 [71\%] w ramach rejestru RESOLVE i 274 [29\%] w ramach rejestru SAVORY), u 12\% rozpoznano zakrzepice na płatkach bioprotezy, w tym u 5 chorych (4\%) leczonych kardiochirurgicznie (SAVR) versus 101 (13\%) leczonych przezcewnikowo (TAVR). Subkliniczna zakrzepica na płatkach bioprotezy istotnie rzadziej występowała u pacjentów przyjmujących antykoagulanty (4\%, 8/224) niż u przyjmujących podwójną terapię przeciwpłytkową (DAPT, dual antiplatelet therapy) $(15 \%, 31 / 208 ; p<0,0001)$. Leki z grupy NOAC były tak samo skuteczne jak warfaryna (3\%, 3/107 v. 4\%, 5/117; $\mathrm{p}=0,72)$. W małej grupie poddanej kontrolnemu CT zakrzepica ustąpiła u wszystkich 36 pacjentów leczonych przeciwkrzepliwie (warfaryna 67\%, NOAC 33\%), natomiast w grupie nieprzyjmującej antykoagulantów przetrwała u 91\% (20 badanych, $p<0,0001$ ). U większości chorych z subkliniczną zakrzepicą na płatkach bioprotezy gradienty na zastawce aortalnej przekraczały $20 \mathrm{~mm}$ Hg i wzrastały o ponad 10 mm Hg (88\%, 12/88) w stosunku do osób z prawidłową funkcją zastawki $(1 \%, 7 / 632 ; p<0,0001)$. Chociaż odsetek udarów mózgu nie różnił się istotnie między grupami, to zaobserwowano zwiększoną tendencję do występowania przejściowego niedokrwienia ośrodkowego układu nerwowego (OUN) (przemijający napad niedokrwienny [TIA, transient ischemic attack]) - 4,18/100 osób/rok v. 0,60/100osób/ /rok; $p=0,0005)$ - oraz wszystkich incydentów niedokrwiennych OUN (udarów i TIA) (7,85 v. 2,36/100 osób/ /rok; $p=0,001$ ). Autorzy podkreślili fakt, że mimo świetnych wyników klinicznych TAVR z protezami nowej generacji, zapobieganie i leczenie subklinicznej zakrzepicy na płatkach zastawki może stanowić szansę dalszej poprawy hemodynamiki oraz odległych wyników leczenia [3]. Obserwacje te mogą zmienić zasady wykorzystywania CT do oceny pozabiegowej pacjentów poddawanych TAVR.

\section{Ostre zespoły wieńcowe}

Szczególnie oczekiwaną analizą spośród badań lekowych, związanych z kardiologią interwencyjną, było badanie GEMINI-ACS-1 (A Multicenter Randomized Trial Evaluating Clinically Significant Bleeding with Low-Dose Rivaroxaban vs Aspirin, in Addition to P2Y12 inhibition, in ACS), realizowane w dużym zakresie również przez ośrodki polskie. Celem tego badania była ocena bezpieczeństwa zastosowania riwaroksabanu w małej dawce zamiast kwasu acetylosalicylowego (ASA, acetylsalicylic acid), w połaczeniu z inhibitorem P2Y12 (56\% pacjentów przyjmowało tikagrelor, pozostali klopidogrel) u pacjentów ze świeżo przebytym (2-10 dni, średnio 5,5 dnia) ostrym zespołem wieńcowym (ACS, acute coronary syndrome). W badaniu wzięło udział 3037 pacjentów (średni wiek 63 lata, 75\% mężczyzn), ze świeżo przebytym ACS, w $87 \%$ przypadków leczonym pierwotną angioplastyką, których poddano randomizacji w stosunku 1:1 do grup leczonej ASA lub leczonej riwaroksabanem w dawce $2 \times 2,5 \mathrm{mg}$. Pierwszorzędowy punkt końcowy, jakim było istotne klinicznie krwawienie na podstawie klasyfikacji krwawień według TIMI (The Trombolysis in Myocardial Infarction bleeding criteria), wystąpił u 5,3\% pacjentów z grupy leczonej riwaroksabanem oraz u 4,9\% z grupy leczonej ASA, co było różnicą nieistotną 
statystycznie (współczynnik ryzyka [HR, hazard ratio] = $=1,09, p=N S)$. Badacze ocenili również częstość powikłań zakrzepowych (zgonu z powodu zawału serca, udaru mózgu, innych chorób układu sercowo-naczyniowego czy też zakrzepicy w stencie) - w tym przypadku również nie wykazano istotnej statystycznie różnicy między grupami (5\% w grupie leczonej riwaroksabanem $[\mathrm{HR}=1,06]$ oraz $4,7 \%$ w grypie leczonej ASA). Podwójną terapię łączącą riwaroksaban w małej dawce z inhibitorem P2Y12 w leczeniu ACS cechowało statystycznie zbliżone ryzyko istotnego klinicznie krwawienia, jak DAPT (dual antiplatelet therapy; tj. ASA + + inhibitor P2Y12). W celu ostatecznego oszacowania skuteczności i bezpieczeństwa takiej terapii wymagane byłoby przeprowadzenie większego randomizowanego badania. Nie ulega wątpliwości, że wyniki badania GEMINI-ACS-1 są przełomowe i mogą zrewolucjonizować dotychczasowe podejście terapeutyczne w ACS [4]. W badaniu po raz pierwszy wykazano możliwość eliminacji ASA z wczesnego protokołu leczenia po ACS, a zarazem dostarczyło danych na temat bezpiecznego łączenia riwaroksabanu (na razie w małych dawkach) z tikagrelorem.

\section{Czynnościowa ocena zwężeń wieńcowych}

Podczas tegorocznego kongresu ACC dużą uwagę poświęcono badaniom służącym ocenie przydatności cząstkowej rezerwy wieńcowej (FFR, fractional flow reserve) - wskaźnika fizjologicznej istotności zwężeń tętnic wieńcowych w codziennej pracy w cath-labie. Badanie COMPARE-ACUTE (Randomised trial of FFR-guided complete revascularization versus infarct artery only treatment in multivessel STEMI patients) zaprojektowano po to, aby ocenić przydatność FFR w zawale serca z uniesieniem odcinka ST (STEMI, ST-elevated myocardial infarction). Pacjenci ze STEMI często mają więcej niż jedną krytyczną zmianę w tętnicach wieńcowych. Obecnie według wytycznych zwykle poszerza się tylko tętnice dozawałową (IRA, infarct-related artery). Celem badania było porównanie strategii leczenia tylko IRA z zabiegiem wielonaczyniowym, z wyborem tętnic leczonych na podstawie FFR (wykonywanej też w pierwszej grupie, ale z zaślepieniem operatora co do jej wyniku i 45-dniowym oknem na kolejne etapy zabiegu). Do badania włączono 885 pacjentów ze STEMI w 24 ośrodkach, w tym w 12 w Europie i Azji. Chorych w stanie stabilnym natychmiast po udrożnieniu tętnicy dozawałowej poddano randomizacji do dwóch grup: tylko FFR (tylko rewaskularyzacja związana z zawałem, $n=590$ ) oraz FFR i przezskórnej angioplastyki wieńcowej (PCl, percutaneus coronary intervention), gdy wynik był mniejszy lub równy 0,80 (pełna rewaskularyzacja, $n=295$ ). Pierwszorzędowym złożonym punktem końcowym była śmiertelność z wszystkich przyczyn, niezakończony zgonem zawał serca, udar mózgu oraz konieczność kolejnej rewaskularyzacji (w tym angioplastyki lub pomostowania aortalno-wieńcowego) w ciągu 12 miesięcy. Pierwszorzę- dowy złożony punkt końcowy wystąpił u 20,5\% ( $n=121$ ) pacjentów poddanych rewaskularyzacji jedynie tętnicy dozawałowej i u 7,8\% $(n=23)$ pacjentów poddanych całkowitej rewaskularyzacji poprzedzonej metodą FFR - różnica ta była istotna statystycznie ( $p<0,001)$. Gdy składowe pierwszorzędowego złożonego punktu końcowego poddano osobnej analizie, nie stwierdzono istotnych różnic w zakresie częstości śmiertelności z wszystkich przyczyn (1,7 v. 1,4\%, 95-proc. przedział ufności [Cl, confidence interval]), niezakończonego zgonem zawału serca (4,7 v. 2,4\%, 95\% Cl) lub udaru mózgu (0,7 v. 0\%). Zaobserwowano jednak znaczne zmniejszenie częstości występowania kolejnych zabiegów rewaskularyzacji wśród chorych, którzy byli poddani całkowitej rewaskularyzacji (6,1 v. 17,5\%, 95\% Cl). Należy podkreślić, że poważne zdarzenie niepożądane związane z FFR wystąpiło jedynie u 2 pacjentów (w grupie poddanej rewaskularyzacji tętnicy dozawałowej). Wyniki COMPARE-ACUTE pokazują, że stosowanie FFR w ostrej fazie STEMI jest bezpieczne, a pełna rewaskularyzacja według oceny FFR pozwala na bardziej precyzyjne leczenie i uzyskanie lepszych wyników odległych. Wyniki te są zgodne z uzyskanymi we wcześniejszych badaniach, w których wskazywano na korzyści wynikające z bardziej kompleksowego podejścia do leczenia STEMI, ale jest to pierwsze randomizowane badanie kliniczne, w którym używano FFR, by precyzyjnie ocenić istotność zwężenia w pozostałych naczyniach wieńcowych. Mimo obaw o zwiększenie złożoności procedury służącej leczeniu zawału serca okazało się, że procedury w grupie poddanej całkowitej rewaskularyzacji były średnio tylko o 6 min dłuższe niż w grupie poddanej rewaskularyzacji ograniczonej do IRA [5]. Co ciekawe, wzrokowo oceniane zwężenia co najmniej 50\% średnicy naczynia wykazywały istotnie obniżoną FFR w około połowie, co potwierdza nieadekwatność luminogramu jako jedynej podstawy wyboru naczynia do angioplastyki.

Największy wpływ na codzienną praktykę w cath-labie najprawdopodobniej będą miały wyniki badań DEFINE-FLAIR (Functional Lesion Assessment of Intermediate Stenosis to Guide Revascularisation) oraz iFR-SWEDEHEART (Instantaneous Wave-Free Ratio versus Fractional Flow Reserve guided intervention). Badania te dotyczyły stosowania, będącego obecnie „złotym standardem”, FFR oraz niewymagającego wazodylatacji, opartego na specjalnym algorytmie komputerowym, iFR (instantaneous wave-free ratio) wykonywanego podczas koronarografii, w celu oceny istotności zwężeń. Do badania DEFINE-FLAIR włączono 2492 pacjentów z chorobą wieńcową (stabilna choroba wieńcowa oraz ACS) w 49 ośrodkach z 17 krajów (Stany Zjednoczone, Europa, Afryka, Azja, Australia). Chory objęto randomizacją w stosunku 1:1 do grup FFR i iFR (średni wiek 65 lat, 76\% mężczyzn, 80\% ze stabilną chorobą wieńcową). Do badania iFR-SWEDEHEART włączono 2019 pacjentów w 15 ośrodkach (Szwecja, Dania, Islandia). Do grupy FFR przydzielono 1007 chorych, a do grupy iFR - 1012. Oba 
te badania były jak dotychczas największymi, w których oceniano przydatność iFR i jego korelację w stosunku do FFR. Podwoiły one liczbę danych dotyczących oceny istotności zwężeń w tętnicach wieńcowych. Obserwacja trwała 12 miesięcy. W badaniu DEFINE-FLAIR liczba badanych naczyń nie różniła się znacząco między grupami iFR oraz FFR (całkowita liczba ocenionych zmian wynosiła, odpowiednio, 1575 i 1608, 1,27 $\pm 0,61$ i 1,29 $\pm 0,63, p=$ $=0,58)$. Średnie wartości pomiarów iFR i FFR były zbliżone do ich progów (średnie iFR $=0,91 \pm 0,09$, średnia wartość FFR $=0,83 \pm 0,09)$. Liczba czynnościowo istotnych zwężeń (tj. zwężeń z wynikiem iFR lub FFR poniżej progu) była istotnie mniejsza w grupie iFR niż w grupie FFR (28,6\% v. 34,6\%, p = 0,004). Pierwszorzędowy złożony punkt końcowy, obejmujący zgon z wszystkich przyczyn, niezakończony zgonem zawał serca oraz nieplanowana rewaskularyzację, wystąpił u 78 z 1148 pacjentów (6,8\%) w grupie iFR oraz u 83/1182 chorych $(7,0 \%)$ w grupie FFR - wynik równocenny. Ryzyko wystąpienia każdego składnika pierwotnego punktu końcowego oraz zgonu z przyczyn sercowo-naczyniowych lub innych nie różniły się znacząco między grupami. Liczba pacjentów, u których występowały objawy niepożądane związane z procedurą, była znacznie niższa w grupie iFR niż w grupie FFR (odpowiednio 39 [3,1\%] v. 385 [30,8\%]; $p<0,001)$, a mediana czasu zabiegu była znacząco krótsza w grupie iFR (40,5 min. v. 45,0 min.; $p=0,001$ ). Ponadto FFR był związany z częstszym występowaniem duszności (1\% w grupie iFR v. 20\% w grupie FFR), bólu w klatce piersiowej (1,5\% w grupie iFR i 7,2\% w grupie FFR), zaburzeń rytmu serca (odpowiednio $0,2 \%$ v. 4,8\%), hipotonii $(0,3 \%$ v. $1 \%)$ oraz konieczności wykonania kardiowersji elektrycznej w celu przywrócenia rytmu zatokowego $(0,1 \%$ w grupie iFR oraz $0,6 \%$ w grupie FFR). W badaniu iFR-SWEDEHEART oceniono 1568 zmian w grupie iFR (1,55 zmian/pacjenta) oraz 1436 w grupie FFR (1,43 zmiany/pacjenta) $(p=0,002)$. Średni iFR wyniósł $0,91 \pm 0,10$, a średni FFR 0,82 $\pm 0,10$. W grupie iFR $29,1 \%$ zwężeń miało znaczenie hemodynamiczne, w porównaniu z 36,8\% w grupie FFR ( $p<0,001$ ). Rewaskularyzacje wykonano u 536 pacjentów z grupy iFR oraz u 569 pacjentów $z$ grupy FFR $(p=0,11)$. Podstawową procedurą rewaskularyzacji u 81,4\% pacjentów była $\mathrm{PCl}$. Pierwszorzędowy punkt końcowy wystąpił u 6,7\% (68/1012 chorych) z grupy iFR oraz u 6,1\% (61/1007 chorych) z grupy FFR (różnica nieznamienna). Liczba zgonów nie różniła się znacząco między grupami - w grupie iFR wystąpiło 15 zgonów, w tym 8 z przyczyn sercowo-naczyniowych, natomiast w grupie FFR było 12 zgonów, w tym 6 z przyczyn sercowo-naczyniowych $(p=0,57)$. Częstość niezakończonego zgonem zawału serca oraz konieczność ponownej rewaskularyzacji również nie wykazały istotnych różnic. W grupie iFR potwierdzono wystąpienie 1 przypadku zakrzepicy w stencie, a w grupie FFR - 2 przypadków. Restenoza w stencie wystąpiła u 1,9\% pacjentów z grupy iFR oraz u 1,8\% z grupy FFR ( $p=0,87)$.
Dyskomfort w klatce piersiowej związany z procedurą wystąpił u 3\% chorych z grupy iFR oraz u 68,3\% pacjentów z grupy FFR ( $p<0,001)$. W obu tych badaniach, o bardzo zbliżonym protokole, wykazano, że wykonanie badania iFR w celu podjęcia decyzji o konieczności rewaskularyzacji jest porównywalne ze „złotym standardem”, jakim jest badanie FFR, przy czym częstość występowania niekorzystnych objawów związanych z procedurą była mniejsza, a czas postępowania krótszy w grupie iFR niż w FFR [6, 7]. Wyniki obu badań jednoznacznie wskazują również, że standardem oceny krążenia wieńcowego w XXI wieku musi być połączenie informacji anatomicznej z fizjologiczną, dostarczaną na przykład metodą rezerwy przepływu.

\section{Przewlekłe okluzje tętnic wieńcowych}

Spore kontrowersje podczas kongresu w Waszyngtonie wzbudziły wyniki badania DECISION CTO (Drug-Eluting Stent Implantation Versus Optimal Medical Treatment in Patients With Chronic Total Occlusion), które wykazały, że leczenie farmakologiczne może być równie skuteczne, co przezskórna angioplastyka w tętnicach wykazujących przewlekłe zamknięcie w ciągu 3 lat obserwacji. Do badania włączono 815 pacjentów z przewlekłą całkowitą okluzją tętnicy wieńcowej (CTO, chronic total occlusion) (trwającą $\geq 3$ mies., ze średnicą referencyjną $\geq 2,5 \mathrm{~mm}$ ) z 19 ośrodków w Azji. Metodą randomizacji do grupy poddanej $\mathrm{PCl}$ oraz farmakoterapii przydzielono 417 chorych, a 398 chorych do grupy otrzymującej jedynie leki. Nie włączano chorych z obwodowymi okluzjami, mnogimi CTO, reokluzją w stencie, okluzją pomostu i frakcją wyrzutową lewej komory (LVEF, left ventricular ejection fraction) mniejszą niż 30\%. Po 3 latach obserwacji nie stwierdzono istotnej statystycznie różnicy w zakresie wystąpienia pierwszorzędowego złożonego punktu końcowego (20,6 v. 19,6\%), a także oddzielnie częstości zgonu, zawału serca, udaru mózgu czy konieczności kolejnej rewaskularyzacji. Nie wykazano różnicy pod względem częstości występowania złożonego punktu końcowego po 5 latach obserwacji $(26,3 \%$ v. 25,1\%; $p=0,67)$, śmiertelności z przyczyn sercowo-naczyniowych $(1,9 \%$ v. 3,6\%; $p=$ $=0,22)$, zawału serca $(1,8 \% v \cdot 1,8 \% ; p=0,93)$ czy ponownej rewaskularyzacji (14,0 v. 11,8\%; $p=0,38)$. Wyniki oceny jakości życia na podstawie kwestionariusza (The Seattle Angina Questionnaire) również nie różniły się znacząco w obu grupach w okresie obserwacji. Zdaniem badaczy wyniki te wskazują, że nie zawsze jest konieczny wybór pierwotnej strategii udrażniania CTO za pomocą $\mathrm{PCl}$, co wiąże się ze znacznym zwiększeniem kosztów leczenia oraz wyższym ryzykiem okołoproceduralnego zawału serca. Należy podkreślić, że było to pierwsze badanie, w których porównano wyniki dwóch metod leczenia u pacjentów z całkowitym lub prawie całkowitym długotrwałym zamknięciem tętnic wieńcowych [8], u pacjentów z potwierdzonym (> 95\%) niedokrwieniem w dorzeczu zamkniętej tętnicy. Wyniki tego badania są 
zgodne z dowodami z poprzednich prób klinicznych sugerującymi, że $\mathrm{PCl}$ nie poprawia długoterminowych wyników leczenia w porównaniu z samą farmakoterapią u pacjentów z chorobą wieńcową, u których nie wystąpiła nagła zmiana objawów i nie występuje ciężka dysfunkcja lewej komory. Należy jednak zwrócić uwagę na fatkt, że w populacjach poddanych faktycznie zabiegowi (innych niż podstawowa analiza wg intencji leczenia - zgodnej z randomizacją), strategia optymalnego leczenia (OMT, optimal medical treatment) nie osiągnęła formalnych wymogów równoważności z PCl.

\section{Stenty bioresorbowalne}

W ostatnim dniu kongresu przedstawiono, rozczarowujące dla wielu zwolenników koncepcji przyszłości PCI należącej do stentów bioeresorbowalnych, promowanych intensywnie jako nowa kategoria urządzeń do angioplastyki wieńcowej (BVS, bioresorbable vascular scaffold), 2-letnie wyniki badania ABSORB III (A Bioresorbable Everolimus-Eluting Scaffold Versus a Metallic Everolimus-Eluting Stent III). Celem tych badań była ocena bezpieczeństwa i efektywności implantacji bioresorbowalnego uwalniającego ewerolimus stentu Absorb BVS ${ }^{\circledR}$ w porównaniu ze stentem Xience $^{\circledR}$ (kobaltowo-chromowym stentem uwalniajacym ewerolimus). Badanie ABSORB III objęło 2008 pacjentów (średni wiek 64 lata, 30\% kobiet), leczonych w 193 ośrodkach, przede wszystkim w Stanach Zjednoczonych. Po potwierdzeniu do 2 zwężeń w różnych naczyniach wieńcowych zostali losowo przydzielani (randomizacja 2:1) do grupy Absorb BVS ( $n=1322$ ) lub Xience $(n=686)$. Oba użyte w badaniu stenty stopniowo uwalniają ewerolimus. Wyniki badania okazały się niekorzystnie dla nowej technologii BVS. Pierwszorzędowy punkt końcowy (zgon sercowy, zawał w zakresie naczynia zrewaskularyzowanego [TV-MI, target vessel myocardial infarction], ponowna rewaskularyzacja z powodu niedokrwienia w zakresie naczynia docelowego [ID-TLR, ischemia-driven target-vessel revascularization]), częściej wystąpił w grupie BVS, zarówno w pierwszym, jak i drugim roku po implantacji; przełożyło się to na znamiennie lepsze wyniki leczenia z użyciem stentu tradycyjnego. Problem dotyczący docelowego naczynia (TLF, target lesion failure - zgon, zawał, niedokrwienie) wystąpił u 11\% w grupie BVS versus 7,9\% w grupie Xience ( $p=0,03$ ). Wśród składowych dominował zawał - $u$ 7,3\% versus $4,9 \%$ ( $p=$ $=0,04$ ), ale częstsze były także: zgon sercowy $1,1 \%$ versus 0,6\%; rewaskularyzacja zależna od niedokrwienia 5,3\% versus 4,3\% ( $p>0,05$ ); zakrzepica w stencie 1,9\% versus $0,8 \%$ - odpowiednio w grupach BVS i Xience ( $p>0,05)$. Mimo formalnie nieprzekroczonego progu równoważności w okresie między 1. a 2. rokiem obserwacji wszystkie wskaźniki zdarzeń klinicznych wykazywały narastający trend na niekorzyść BVS. Pacjenci, którym wszczepiono Absorb, cechowali się podwyższonym ryzykiem wystąpienia niekorzystnych zdarzeń po 2 latach obserwacji, przy czym istotnym czynnikiem powodującym te negatywne skutki było umieszczenie stentu w naczyniach o średnicy 2,5 mm lub mniejszej. Producent BVS sugeruje też krytyczną rolę ewoluującej techniki wszczepiania BVS, wymagającej złożonej sekwencyjnej pre- i postdylatacji, która może wpływać na poprawę wyników leczenia z użyciem BVS. Trwa przedłużona obserwacja Absorb IV, której celem jest ocena skuteczności i bezpieczeństwa stentu Absorb BVS ${ }^{\circledR}$ implantowanego według najnowszych rekomendacji, w obserwacji ponad 3-letniej, czyli po całkowitym rozpuszczeniu polimeru [9]. Niestety, rozczarowujące wyniki dotychczasowych badań doprowadziły obecnie do wstrzymania jego rutynowej dostępności w Europie. Nasuwa się też refleksja prawna, dotycząca łatwości wprowadzania na rynek nowych urządzeń medycznych, nie zawsze z dopracowanymi wskazaniami i protokołami stosowania - szczególnie w porównaniu ze standardami kwalifikacji nowych leków.

\section{Piśmiennictwo}

1. Reardon MJ, Van Mieghem NM, Popma JJ, et al. SURTAVI Investigators. Surgical or transcatheter aortic-valve replacement in intermediate-risk patients. N Engl J Med. 2017; 376(14): 1321-1331, doi: 10.1056/ /NEJMoa1700456, indexed in Pubmed: 28304219.

2. Nishimura RA, Otto CM, Bonow RO, et al. 2017 AHA/ACC Focused Update of the 2014 AHA/ACC Guideline for the Management of Patients With Valvular Heart Disease: A Report of the American College of Cardiology/American Heart Association Task Force on Clinical Practice Guidelines. J Am Coll Cardiol. 2017; 70(2): 252-289, doi: 10.1016/j. jacc.2017.03.011, indexed in Pubmed: 28315732.

3. Chakravarty T, Søndergaard L, Friedman J, et al. RESOLVE, SAVORY Investigators. Subclinical leaflet thrombosis in surgical and transcatheter bioprosthetic aortic valves: an observational study. Lancet. 2017; 389(10087): 2383-2392, doi: 10.1016/S0140-6736(17)30757-2, indexed in Pubmed: 28330690.

4. Ohman EM, Roe MT, Steg PG, et al. Clinically significant bleeding with low-dose rivaroxaban versus aspirin, in addition to $\mathrm{P} 2 \mathrm{Y} 12$ inhibition, in acute coronary syndromes (GEMINI-ACS-1): a double-blind, multicentre, randomised trial. Lancet. 2017; 389(10081): 1799-1808, doi: 10.1016/ /S0140-6736(17)30751-1, indexed in Pubmed: 28325638.

5. Smits PC, Abdel-Wahab M, Neumann FJ, et al. Compare-Acute Investigators. Fractional flow reserve-guided multivessel angioplasty in myocardial infarction. N Engl J Med. 2017; 376(13): 1234-1244, doi: 10.1056/NEJMoa1701067, indexed in Pubmed: 28317428.

6. Davies JE, Sen S, Dehbi HM. Use of the instantaneous wave-free ratio or fractional flow reserve in PCl. N Engl J Med. 2017; 376(19): 1824-1834, doi: 10.1056/NEJMoa1700445, indexed in Pubmed: 28317458.

7. Götberg M, Christiansen EH, Gudmundsdottir IJ, et al. iFR-SWEDEHEART Investigators. Instantaneous wave-free ratio versus fractional flow reserve to guide PCI. N Engl J Med. 2017; 376(19): 1813-1823, doi: 10.1056/NEJMoa1616540, indexed in Pubmed: 28317438.

8. Park SJ, et al. Optimal medical therapy with or without stenting for coronary chronic total occlusion - DECISION-CTO. American College of Cardiology Annual Scientific Session (ACC 2017), Washington, DC, March 18, 2017.

9. Ellis S, Kereiakes DJ, et al. A bioresorbable everolimus-eluting scaffold versus a metallic everolimus-eluting Stent III - ABSORB III. American College of Cardiology Annual Scientific Session (ACC 2017), Washington, DC, March 18, 2017. 